\title{
Tjenestepiken som ble feilbehandlet
}

I mars 1907 søkte tjenestepiken Thora Olsen i Kristiania legehjelp for frostsår på hendene. Praktiserende lege Anton Enger (1866-1922) brukte bl.a. røntgenstråler i behandlingen, men resultatet ble ikke som forventet. Fingrene ble ødelagt, slik at hun ble «udygtig til arbeide og til ved sine hænders gjerning at ernære sig selv». Pasienten krevde erstatning, og det ble oppnevnt sakkyndige fordi svært få leger hadde tilstrekkelig kunnskap og erfaring med den nye røntgenbehandlingen. Tidsskriftet omtalte saken i tre korte artikler $(1909 ; 29: 31-2,180,465-6)$. Partene ble til slutt enige.

\section{Lægers ansvar for behandling. Doktor A. Engers Røntgenbehandling.}

«(...) Doktor Enger uttalte, at han dog ikke ansaa sig juridisk forpligtet dertil som følge av nogen feil ved behandlingen, men vel til en viss grad moralsk forpligtet. Erstatningsspørsmaalet, som havde været under forhandling mellem parternes antagne retsfuldmægtige, fandt senere en tilfredsstillende løsning, idet hr. E. vedtok at betale en større sum i skadeerstatning, hvorefter Thora Olsen helt tilbakekaldte sin klage mot doktoren. Hendes begjæring om straf er tidligere tilbakekaldt.

De opnævnte sakkyndige skulde netop ha avgit sin erklæring, da de fra politiet mottok meddelelse om, at saken var ordnet ved forlik.» 